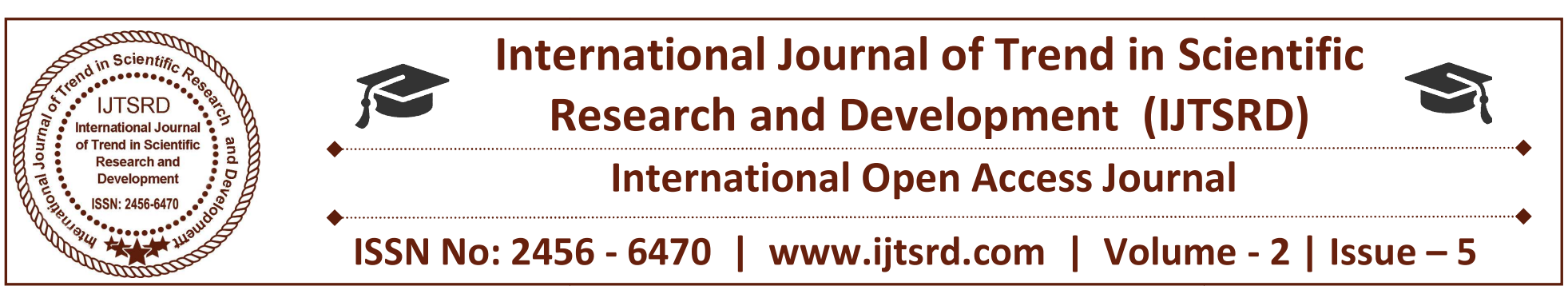

\title{
Impact Assessment of Fluorosis Mitigation Project, A Case Stydy of Nagour
}

\author{
Hukam Singh Raj Purohit ${ }^{1}$, Dr. Bharat Nagar ${ }^{2}$ \\ ${ }^{1}$ Research Scholar, ${ }^{2}$ Professor \& Head \\ Department of Civil Engineering, Jagannath Gupta Institute of Engineering and Technology, \\ Jagannath University, Jaipur, Rajasthan
}

\begin{abstract}
The present study has been undertaken to evaluate the impact assessment of the fluorosis mitigation project in the Nagaur district (Raj). Nagour is a centrally located district of Rajasthan state of India which is a part of great Indian Thar Desert. Average rainfall in the district is $361.65 \mathrm{~mm}$, which means quite low level in comparison with $531 \mathrm{~mm}$ in Rajasthan and $1200 \mathrm{~mm}$ in India. also the district has no perennial river and the main sources of water supply in the district is ground water which invariable does not confirm to BIS and WHO Standards as it contains excess of fluoride, nitrate and salinity. As per National Rural Water Quality Monitoring and Surveillance Programme, the Nagour is ranked second after Barmer that has $65.64 \%$ quality affected drinking water sources. Despite this quality problem, most of area is over exploited. Moreover, cyclic drought has severely affected recharge of aquifers, which causes limited quantity of ground water.
\end{abstract}

Fluoride in drinking water of Rajasthan is found to originate from various rocks. These rocky belts extended from Delhi to Gujarat. The geological distribution of rocks in Rajasthan revels that the fluoride yielding areas occupies large areas of eastern and southeast parts of the state. Also Rajasthan has mica mines, where the ground water is rich in fluorides.

Government of Rajasthan is implementing the fluorosis mitigation programme with the help of the three approaches i.e community based, school based and hospital based in the 986 villages and seven towns of the nagour district.
The impact assessment will help for the better understanding of community participation and the health effect of the interventions. The conclusions of the impact assessment may determine required recommendations and focus on community participation and improvement in their health.The conclusions drawn from this study will outline the need for capacity building of the doctors, paramedical staff and Panchayati Raj Institutions. Administrative capability and reduction in the diseases were evaluated using questionnaires and interpersonal communications.

Keywords: Fluorois Mitigation, Community Based Approach, Hospital Based Approach, School Based Approach, Panchayati Raj Institutions, Interpersonal Communication.

\section{INTRODUCTION}

Nagour is a centrally located district of Rajasthan state of India which is a part of great Indian Thar Desert. Average rainfall in the district is $361.65 \mathrm{~mm}$, which means quite low level in comparison with 531 $\mathrm{mm}$ in Rajasthan and $1200 \mathrm{~mm}$ in India. also the district has no perennial river and the main sources of water supply in the district is ground water which invariable does not confirm to BIS and WHO Standards as it contains excess of fluoride, nitrate and salinity. As per National Rural Water Quality Monitoring and Surveillance Programme, the Nagour is ranked second after Barmer that has $65.64 \%$ quality affected drinking water sources. Despite this quality problem, most of area is over exploited. Moreover, cyclic drought has severely affected 
recharge of aquifers, which causes limited quantity of ground water

As per the norms of the government of Rajasthan service level of 100 LPCD 755 LPCD shall be maintained in the urban and rural area.

In the Nagour district service level in 11 towns of urban area in the district is ranging from 35 LPCD to 94 LPCD, Which are below the level of Government of Rajasthan.

Beside, 2 towns are getting water supply once in three days and 4 towns once in 2 days with average supply hour of 1 to 2 hours. Water supply is so limited because of the above situation.

\section{Rural area}

\begin{tabular}{|c|c|c|c|c|}
\hline $\begin{array}{l}\text { S. } \\
\text { No }\end{array}$ & $\begin{array}{c}\text { Name of } \\
\text { Tehsil }\end{array}$ & $\begin{array}{c}\text { No. of } \\
\text { village } \\
\text { s }\end{array}$ & $\begin{array}{l}\text { Estimated } \\
\text { Population }\end{array}$ & $\begin{array}{l}\text { No. of } \\
\text { House } \\
\text { holds }\end{array}$ \\
\hline 1 & Degana & 112 & 178675 & 35735 \\
\hline 2 & Didwana & 170 & 339900 & 67980 \\
\hline 3 & Jayal & 136 & 268245 & 53649 \\
\hline 4 & Ladnu & 97 & 188445 & 37689 \\
\hline 5 & Makrana & 119 & 238110 & 47622 \\
\hline 6 & Merta & 1 & 425 & 85 \\
\hline 7 & Nagaur & 48 & 75480 & 15096 \\
\hline 8 & Nawa & 193 & 319765 & 63953 \\
\hline 9 & Parbatsar & 110 & 222300 & 44460 \\
\hline & TOTAL & 986 & $18,31,345$ & $3,66,269$ \\
\hline
\end{tabular}

Urban area

\begin{tabular}{|c|c|c|c|}
\hline $\begin{array}{c}\text { S. } \\
\text { No }\end{array}$ & Name of tehsil & $\begin{array}{c}\text { Estimated } \\
\text { population }\end{array}$ & $\begin{array}{c}\text { No of } \\
\text { households }\end{array}$ \\
\hline 1 & Degana & 16383 & 3036 \\
\hline 2 & Didwana & 53749 & 8451 \\
\hline 3 & Kuchaman city & 61969 & 9643 \\
\hline 4 & Ladnu & 65575 & 10050 \\
\hline 5 & Makrana & 116295 & 16022 \\
\hline 6 & Nawa & 22088 & 3754 \\
\hline 7 & Parbatsar & 15172 & 2617 \\
\hline & & $\mathbf{3 5 1 2 3 1}$ & $\mathbf{5 3 5 7 3}$ \\
\hline
\end{tabular}

\section{Importance and relevance of the study}

\section{A. Flourosis problem in Rajasthan}

Fluoride in drinking water of Rajasthan is found to originate from various rocks. These rocky belts extended from Delhi to Gujarat. The geological distribution of rocks in Rajasthan revels that the fluoride yielding areas occupies large areas of eastern and southeast parts of the state. Also Rajasthan has mica mines, where the ground water is rich in fluorides

Over a period of time the number of villages affected by fluoride has increased i.e., in the year 1973, there were 1871 villages with fluoride levels over $3 \mathrm{mg} / 1$. By 2001, this number has risen to 10,342 villages, an increase of more than five times. This makes Rajasthan the most severely affected state in India, with millions crippled as the result of consuming excessive amounts of fluoride. All the 33 districts have been declared as fluoride prone areas. Among all the district worst affected are Nagour, Jaipur, Sikar, Jodhpur, Barmer, Ajmer, Sirohi, Jhunjhunu, Churu, Bikaner, Ganganagar etc.

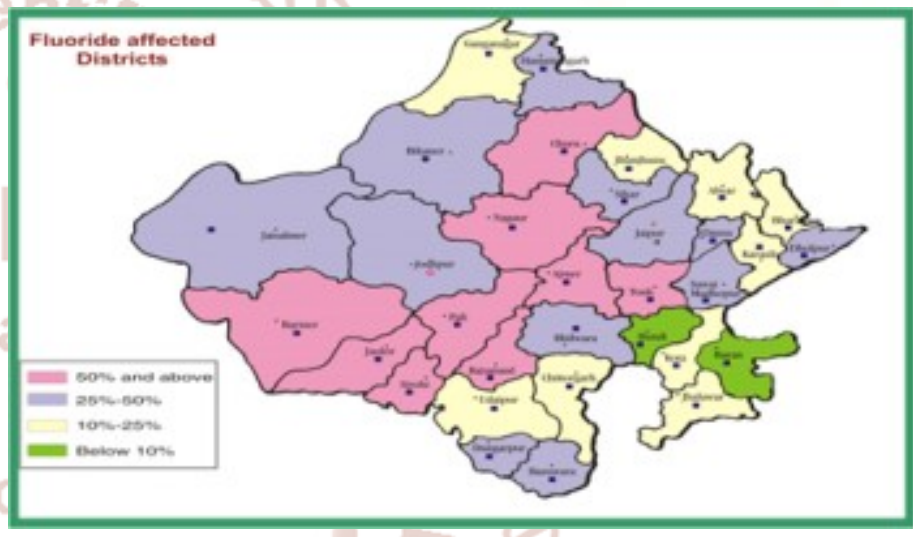

One of the major bottlenecks is, unlike all other diseases, Fluorosis disease symptoms, signs and manifestations can appear differently in different people. This depends upon the (1) body physiology, (2) nutritional standards and (3) hormonal profile of an individual. It is also a fact a wide range of health complaints may appear, starting from extreme weakness fatigue, nausea, pain in the stomach, loss of appetite, tendency to urinate more, low haemoglobin, joint pains, stiffness of joints, unable to walk, etc. Many of the health complications are often dismissed as non-specific by the Doctors. This is a major issue which need correction. In this era of specialization and super specialization, Doctors often view a patient attending the OPDs through

\section{B. Who are the victims and spread of the disease?}

The infants, children, pregnant lady, lactating mothers, adolescent girls and women of all age groups are the victims of fluoride poisoning. Besides, men of all age groups including boys in adolescence are victims of fluoride poisoning / fluoride toxicity and / or Fluorosis disease. In short the community in a 
- Village, $\bullet$ Tehsil $\bullet$ Block, and $\bullet$ District are the target population of FMP. There are early health complaints as well as late health complaints. The FMP is keeping the window open to address all concerned so that the goal of FMP i.e. Mitigate Fluorosis disease in the community, is achieved, during a period of 40 months when the FMP is implemented, monitored and impact assessment carried out in Nagaur district in the specified locations. To reach out to all vulnerable groups of the society to prevent and control from Fluoride poisoning / Fluorosis is a major Policy decision.

\section{Overview of the problem of Fluorosis:}

Observations are from endemic states for Fluorosis in India and Rajasthan in particular. Pregnant women suffer from loss of appetite, nausea, vomiting, etc, during early stages of pregnancy. They tend to consume during that period a variety of substances including churans. They also have special likes and dislikes. They tend to consume certain food items prepared either at home or collected from street vendors, viz. Panipuri, Golgappa, Dahibella, Namkins, Tamarind based chutneys sprinkled with special spices viz. Black Rock Salt $(\mathrm{CaF} 2=157 \mathrm{ppm}$ Fluoride) .It therefore emerges that pregnant women / or lactating mothers can be exposed to Fluoride through food, beyond permissible limits (i.e. $1.0 \mathrm{mg} / 1$ or $1.0 \mathrm{ppm}$ is the maximum body can tolerate) through any of the 5 major sources for fluoride viz

\section{Fluoride from Food, food products and beverages:}

Fluoride containing food, snacks and beverages has become very popular among the masses . The main source of Fluoride is by using black rock salt/ sandha namak or vrat ka namak. This has $157 \mathrm{ppm}$ fluoride. Black rock salt containing spices are sold in the market. The people like it because of its aroma and tangy taste. Using Black rock salt containing spices are used in regular homes (rich or poor) to cook vegetables and Dhal. It is used to sprinkle over Dahi, Achar, Chutneys. It is also used to sprinkle over salads, fruit chat, lime juice. Every kitchen shall have a bottle of Black rock salt that is the experience. All street foods - viz. Bhel puri, Pani puri, Chaat, Golgappa, fruit juices and even cut fruits on road side smear black rock salt. Consuming Black tea or Lemon tea, contain considerable fluoride .Tea with calcium rich milk is safe. The Community may not know that Fluoride is a poison (Jahar) and at times, fluoride entry to the body is more than the untreated ground water. Awareness generation and Diet Editing would address the above issues.

\section{E. Fluoride from drinking untreated ground water:}

The concept that Fluorosis is caused by Drinking water Fluoride content, is true, but it is only one of the 5 main routes of Fluoride entry to the body. The FMP therefore is keeping the major focus on provision of safe water with Fluoride not exceeding the upper limit $1.0 \mathrm{mg} / \mathrm{l}$ (BIS guidelines less the better as Fluoride is injurious to health.

\section{F. Fluoride from use of fluoridated dental products:}

It is important to point out how the new-born, infants and children are affected by Fluoride poisoning as pregnant women ingest fluoride. The information is made clear so that appropriate strategy is developed and project implementation stages well defined. Packaged baby food, soya based baby foods have high fluoride.

\section{G. Fluoride from Industrial Emission:}

Inhaling fluoride dust and fumes, if residing near an industry using Fluoride salt or acid and emitting Fluoride dust and fumes to the atmosphere / settles on agricultural crops is also causing damage to health. Those living near small and large scale industries, using Fluoride salt and / or Hydrofluoric acid, the dust and fumes can be inhaled is common. There are small and large scale Chemical industries in Nagaur. The community living in the neighbourhood would be watched for Fluoride poisoning.

\section{H. Fluoride from drugs:}

Fluoride containing drugs are often prescribed (available in different brand names)

For certain ailments for long term treatment to get relief from:

a) Otto sclerosis (Hard of hearing- Drugs contain Fluoride)

b) Depression (Majority of anti-depressants contain Fluoride)

c) Osteoporosis (Bone atrophy - Drugs contain Fluoride)

When the treatment is inevitable, the treating Physician may have to monitor the patient for GI problems, polyuria, polydipsia, fatigue and weakness due to Fluoride poisoning. Therefore the Doctors would be sensitized on all aspects of Fluorosis. 


\section{Water sources in Nagour}

The surface water sources are none except a few salt lakes. There is a salt lake Sambhar Lake at Southwest of Didwana, having an area of 777 hectares. Nawa Tehsil also shares a part of Sambhur Lake in jaipur. There are 8 ponds in the district out of these, 5 are in Degana and 3 in Parbatsar blocks.

The deeper aquifers are being exploited extensively through low to median duty tube wells. The auafier a parameters of dug wells and tube wells have been studied from pumping tests. The yield of tube wells/dug wells in Nagour sandstone area varies from $6.5 \mathrm{~m} 3 / \mathrm{hr}$ to $36 \mathrm{~m} 3 / \mathrm{hr}$. the depth to water levels in Nagour district ranges from 10-80 meter below ground level. There is water level decline in many areas in the district, viz. Kuchaman city, Degana, Didwana and few others, and it is to the extent of 10 to $25 \mathrm{~m}$ has been recorded during the last 15 years.

\section{Ground water quality}

The water in Nagour district is generally brackish to saline with a few pockets having fresh water with electrical conductivity less than $\ 2000$ Micro Mohos/cm at 25 Degree Centigrade.

There are large areas with high fluoride

The fluoride content of Nagour district so far detected varies from $1 \mathrm{mg} / 1$ to $14.82 \mathrm{mg} / 1$.

\section{III.Health problem}

In view of poor water quality and scarcity of potable water and high fluoride contents in ground water, the community suffers from all the three forms of fluorosis and associated health issues.

The study conducted in Nawa Tehsil of Nagour district, in January 2011, by R. Gautam and his team from Jaipur university of Rajasthan has shown fluoride in different zones ranged from $0.64 \mathrm{mg} / \mathrm{l}$ to $14.82 \mathrm{mg} / 1$; where $13 \%$ samples are found with fluoride in permissible limit. However $86.96 \%$ has found beyond permissible limit.

Fluoride concentration ranged from (1) 1.10 to 14.82 $\mathrm{mg} / \mathrm{l}$ in 3 different southeast zones (2) in the eastern zone, fluoride concentration was recorded and ranged from 1.52 to $5.13 \mathrm{mg} / \mathrm{l}$ (3) whereas, in south zone it was found between 0.64 to $3.63 \mathrm{mg} / \mathrm{l}$.

\section{Sources of fluoride in ground water}

It has been recorded in India week 2012 by Mohd. Arif from PHED Bhilwara, Rajasthan and his team, the sources of fluoride in ground water are from the following minerals found in the geological crust.

$>$ Fluorite( fluorspar)

$>$ Fluorapatite (apatite)

$>$ Micas

$>$ Biotite

$>$ Muscovite

Lepidolite

Amphiboles

> Hornblende

$>$ Tremolite

Actinolite

$>$ Topaz

$>$ Rock phosphate

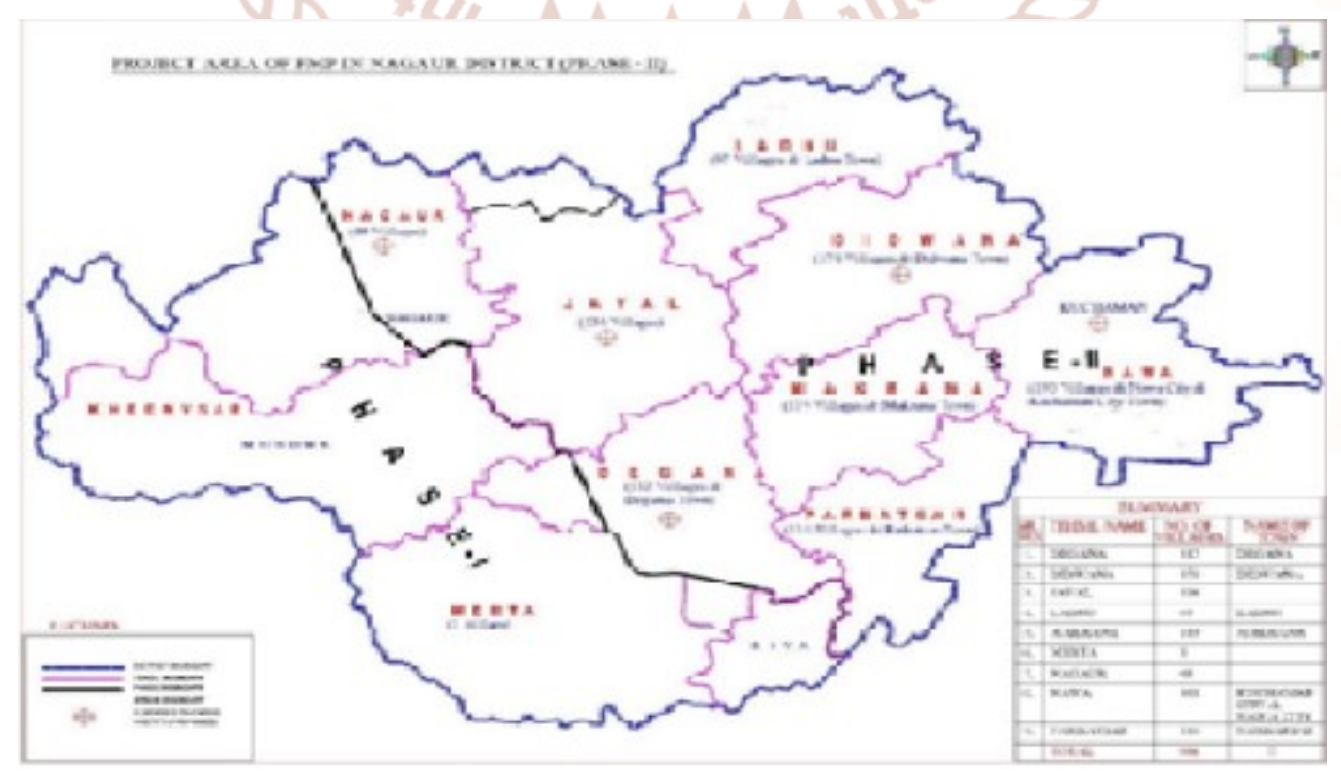


International Journal of Trend in Scientific Research and Development (IJTSRD) ISSN: 2456-6470

\section{Fluorosis situation in Nagour district}

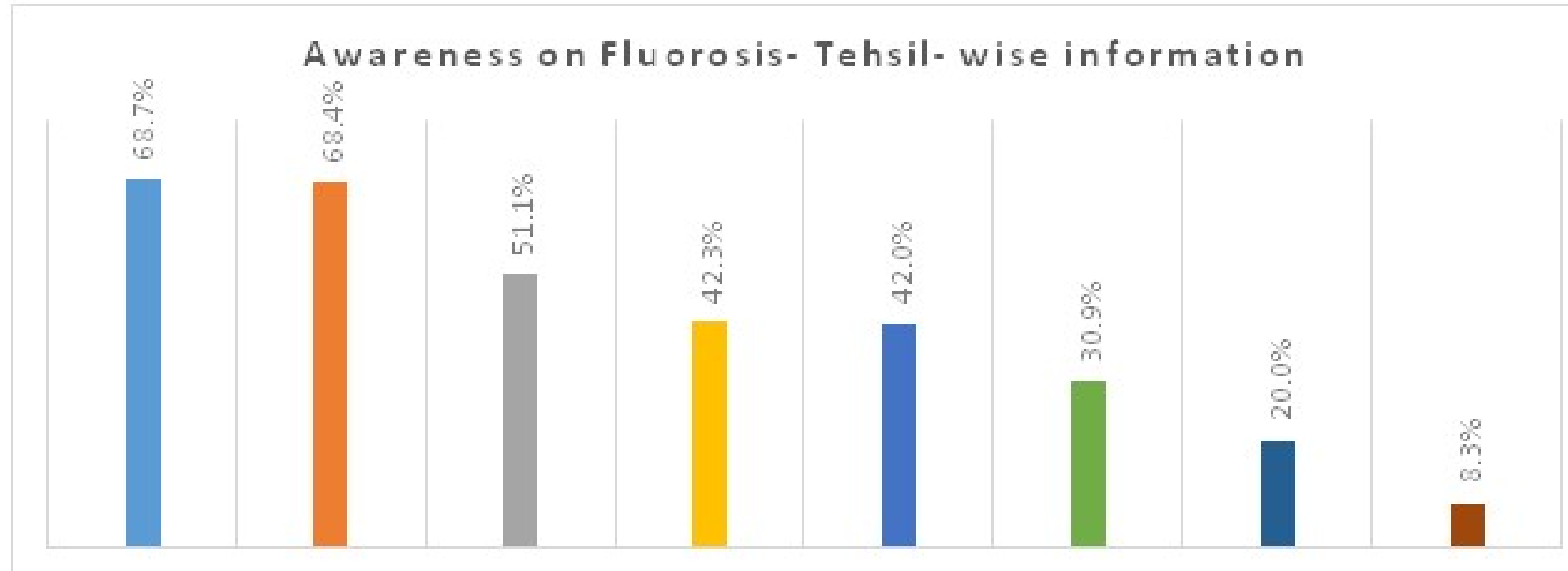

NAWA MAKRANA DEGANA PARBASAR LADNUN DIDWANA JAYAL NAGAUR

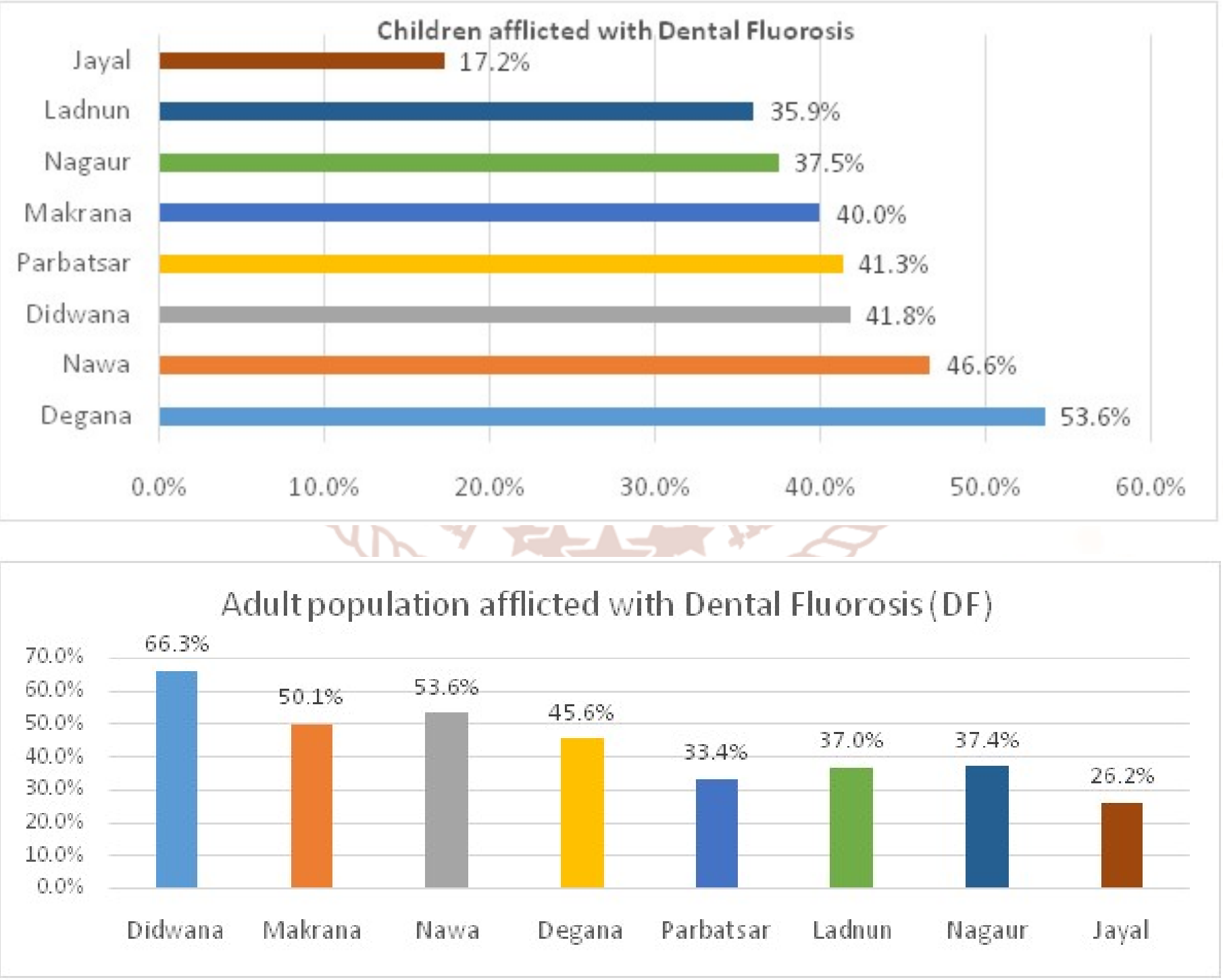




\section{Graphical representation of drinking water situation of Nagaur district}

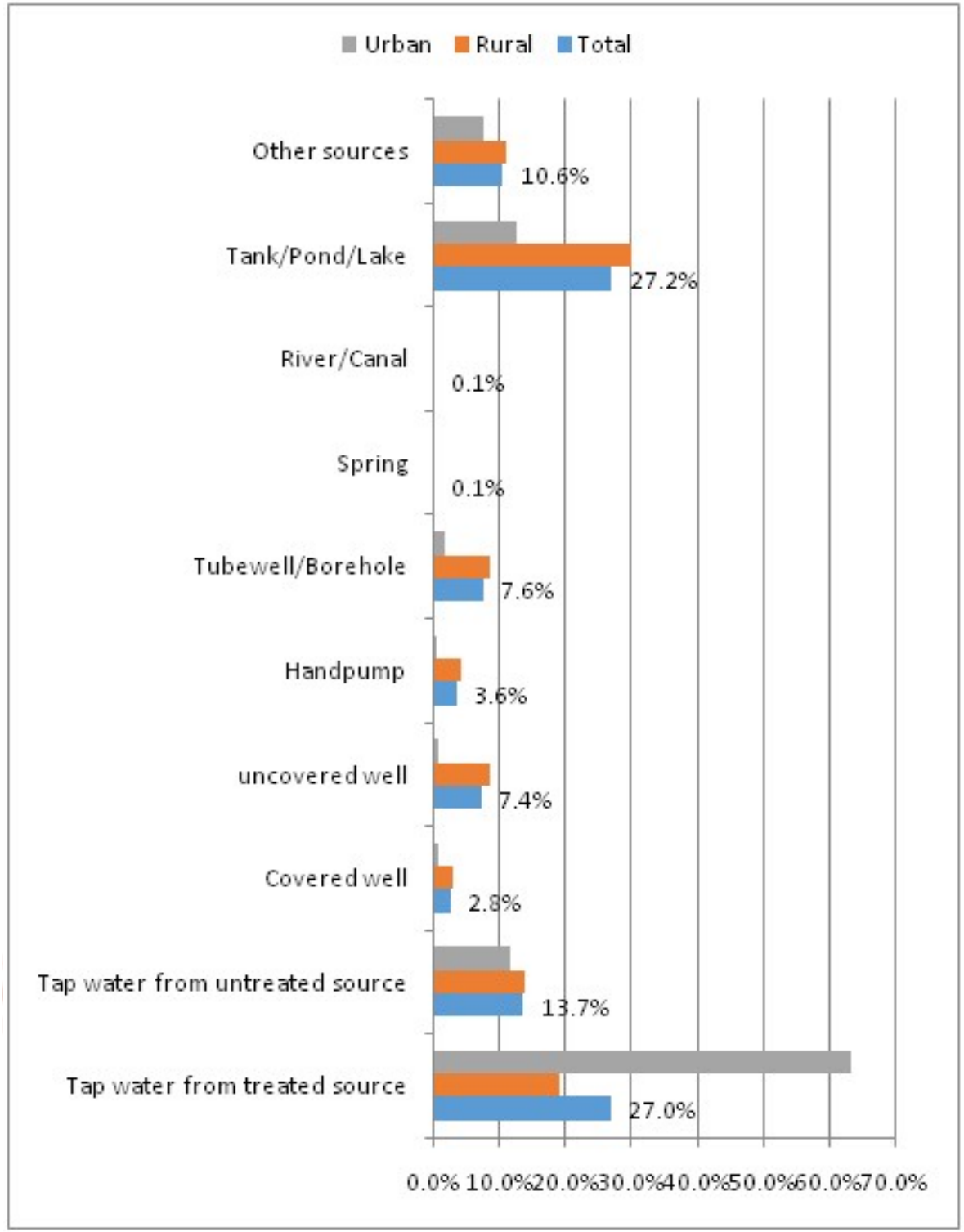

\section{Flourisis disease}

The people of Nagour district, those who are unwell and victim of fluorosis would seek assistance from doctors posted in government hospitals as well as in private hospitals.

As the patients, reaching out to hospitals is unfortunately not attended to, for a variety of reasons, it is necessary to address issues through a few selected hospitals/health delivery outlets in the districts. So that unwell and flouorised victims from all parts of Nagour are able to reach health delivery outlets and receive proper care in hospitals and dealt with in a manner, they get relief from fluorosis disease which has not happened in Rajasthan state until date.

\section{SUMMARY}

- Children to the tune of $39.2 \%(1,802$ nos.) are reported with Dental Fluorosis

- Members of the households to the tune of $35.6 \%(6,506$ nos.) are reported with Dental Fluorosis

- Members of the households to the tune of $53.7 \%(9,821$ nos.) and $20 \%(3,659$ nos.) are reported with early warning signs and Skeletal Fluorosis respectively.

- The populations to the tune of nearly $69 \%(12,633)$ are consuming food items contaminated with fluoride unknowingly.

- Nearly $44.2 \%$ (1,584 nos.) families are aware about the Fluorosis disease. 


\section{METHODOLOGY}

Objective: To mitigate Fluoride poisoning and Fluorosis disease in the population of Nagaur district, which include young and old, men and women of all age groups of urban and rural areas of the district, through approaches which are proven meaningful ".

\section{Methodology:}

The flourosis management component would be implemented through approaches given below:

\section{A. Hospital base}

$>$ To construct five flouriosis diagnostic labs in government hospitals

$>$ To procure and provide the necessary euipmnet, chemicals, plastics and glass wares and accessories

$>$ To print adequate copies of pre coded formats

$>$ To develop capacity of laboratory technicians

$>$ To develop capacity of ANMs \& ASHAs

$>$ To organize $\mathrm{CME}$ on correct diagnosis

$>$ IEC activities

$>$ To conduct first, second and third impact assessment

\section{B. School base}

To update the list of the UPS, Secondary, senior secondary schools

$>$ To coordinate with the school principals

$>$ To develop the capacity of school teachers

$>$ To screen dental flourosis and bone deformity

$>$ To identify and train health assistants

$>$ To develop the capacity of health assistants

$>$ To check hemoglobin level of the students

$>$ To collect urine samples

$>$ To organize group counseling

$>$ To develop IEC material

$>$ To conduct first, second and third impact assessment

\section{Community base}

$>$ To identify and develop skills in field investigators

$>$ To develop software using android technology and cloud networking to conduct $\mathrm{HH}$ survey

$>$ To develop capacity of PRI members

$>$ To conduct HH survey

$>$ To collect and analyze all the drinking water sources

$>$ To organize Focus group discussions

$>$ To prepare social mapping through the PRA

$>$ To organize street plays
To conduct first, second and third impact assessment

\section{Communication Approaches}

Advocacy : To influence and engage decision makers to provide polices, funding organizational support and commitment for safe drinking water initiatives. The aim is to raise the issues of safe drinking water higher on policy agenda. This will increase commitment and action among decision makers and key influencers for adequate and safe drinking water. The advocacy through:

$>$ Advocacy at state and district level

> Advocacy with district administration and relevant authorities responsible for rural drinking water

Advocacy with other line department ministers Advocacy through media

Advocacy with private sector and other organizations/

$>$ Field visits

$>$ Process documentations

Seminars and conferences.

\section{Community Mobilization}

An approach used to initiate dialogue among community members to deal with critical issues of safe drinking water. This approach is especially effective in rural setting like in the District of Nagaur where communities from close knit units; and if supported by opinion leaders and other influential sources can effect change from within, making it sustainable. Communities need to be involved and engaged in identifying their problems as well as solutions for them. Solutions given from out side the community are rarely sustained as there is no ownership. Thus it would be critical to engage with communities and ensure their participations. Frontline workers and PRIs members can also play an instrumental part in promoting the mobilization in favor of certain behaviors

\section{Mass Media}

Mass media is an important medium to communicate effectively with a larger number of people by leaving them with powerful image. It can overcome barriers of literacy and language and it is ideal for delivering a simple, clear and focused messages. Although there are several media dark areas in the state, there has been rapid progress towards increased TV and radio coverage and penetration. Mass media can support community mobilization and interpersonal communication efforts; promote specific behavior 
through multiple activities and products such as radio and TV Shows, news papers and magazines; enhance the credibility of non - professionals such as community volunteers as reliable sources of information and services; convey important logistical information easily

\section{Outdoor and Folk Media}

According to the context, the stakeholders and the resources available a mix of different media will be used to sensitize on key aspect of the FMP and promote key behavior especially in media dark areas. The communication medium can be range from the more common ones such as hoardings and wall paintings as well as traditional ones, such as folk arts and theater and can be used as reinforcement to IPC and community mobilization activities. Combining different same messages related to key behavior also promotes effective behavior change. For example messages on print materials like flyers, leaflets and folk theater when combined with IPC can become more effective. These medium will be used to reinforce the key messages among the participants. Integrated approaches to ensure that all the messages related to safe drinking water are consistent and reinforced each other.

\section{Monitoring Indicators - IEC}

$>\%$ increase in the awareness level

$>$ At present, level of awareness of fluorosis diseases is $44.2 \%$, which will be increased up to $100 \%$

$>$ In $1^{\text {st }}$ phase, at least $44.2 \%$ population which is already aware about the fluoride disease should not consume the fluoride water

$>$ In $2^{\text {nd }}$ phase rest of population i.e. $57.8 \%$ population will be aware not to consume fluoride contaminated water

$>100 \%$ population should use the fluoride free food items

$>\%$ increase in the safe handling of drinking water.

$>\%$ increase in the rain water harvesting structures
$>\%$ increase in the women participation in the planning, implementation and monitoring of the plan

$>\%$ increase in the water samples testing and their remedial measures

$>\%$ decrease in the dental fluorosis

$>\%$ decrease in the anemic children

$>$ Identification of $100 \%$ fluoride contaminated drinking water sources and their painting ( RED SIGN)

$>100 \%$ mapping of water sources through the PRA Maps

\section{HRD Strategies and Activities}

Creating awareness among stakeholders on water and fluorosis issues by educating them on impact of water and sanitation on health and poverty.

Ensure behavior change in community on prevailing water management practices.

$>$ Generating demand for potable water and sanitation facilities on the basis of felt need.

Capacity building of all stakeholders to enable them to utilize and benefit from the water and fluorosis management .

Convergence with related programme like MNREGA, NRHM, SSA, ICDS, $12^{\text {th }}$ Finance Commission, BRGF etc.

Problem mitigation, trouble shooting and debottlenecking

Impact assessment

\section{Monitoring Indicators - HRD}

$>$ Number of ASHAs, ANMs trained

$>$ Number of doctors trained under CME

$>$ Number of health workers trained

Number of PRIs oriented

Number of laboratory person trained

Number of diet counselor trained

Number of persons trained for $\mathrm{Hb}$ testing

$>$ Number of field functionaries trained.

$>$ Number of local persons trained

\section{Steps for the interventions}

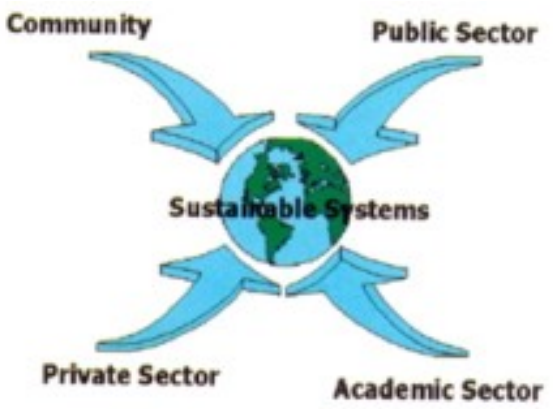

STAGE-1: Human Resources Development STAGE-1: Sunvey STAGE -E Intenvertions 
International Journal of Trend in Scientific Research and Development (IJTSRD) ISSN: 2456-6470

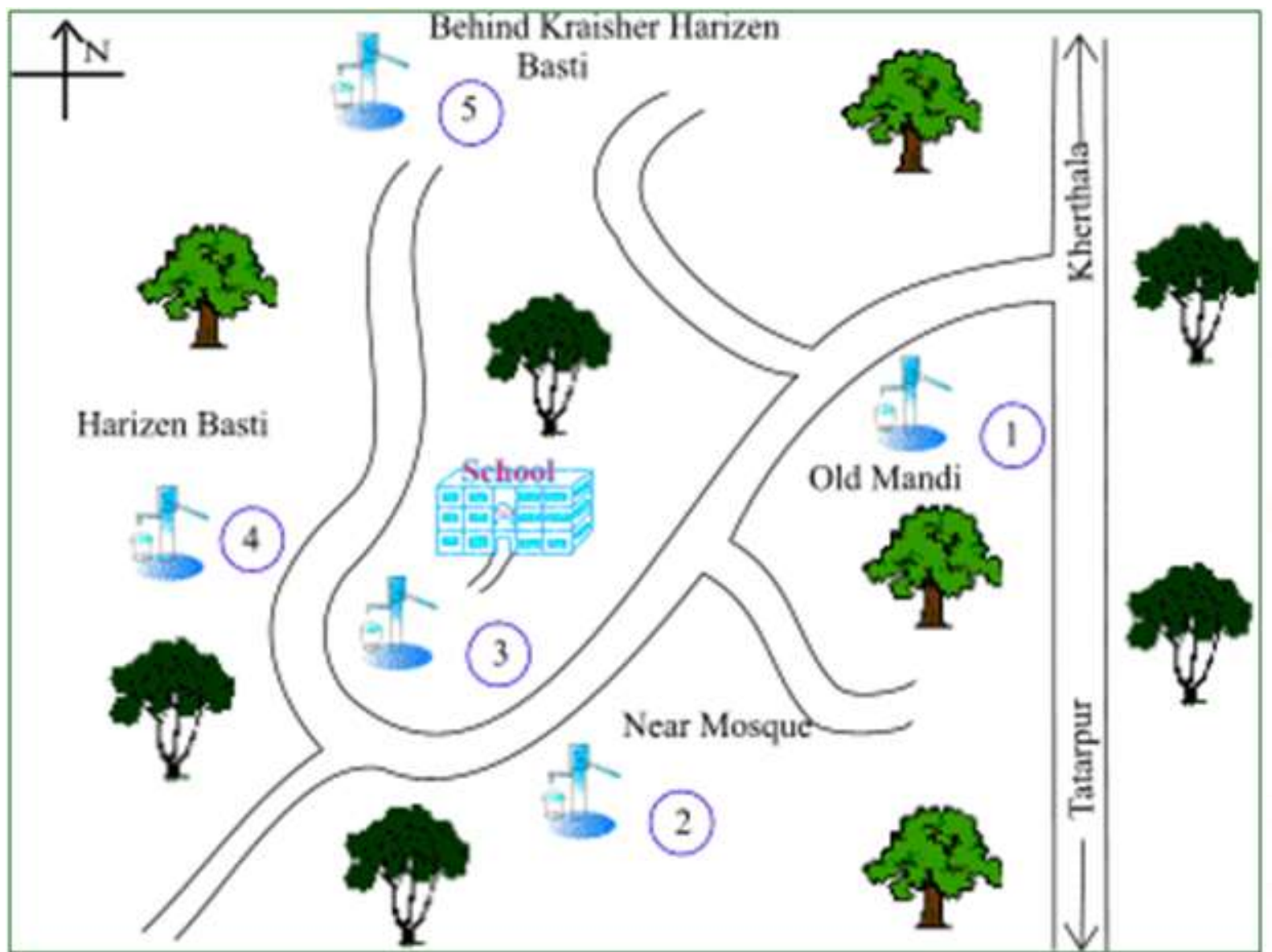

\section{Sanitary survey}

\begin{tabular}{|c|c|c|c|c|}
\hline Strata & Network I & Network II & Network III & Network IV \\
\hline $\begin{array}{c}\text { Grass Root } \\
\text { Level }\end{array}$ & $\begin{array}{c}\text { Mechanic } \\
\text { /Panchyat members }\end{array}$ & $\begin{array}{c}\text { Health Workers/ } \\
\text { Auxiliary nurse/ } \\
\text { mid-wife }\end{array}$ & $\begin{array}{c}\text { Anganwari } \\
\text { Workers }\end{array}$ & $\begin{array}{c}\text { Members of local } \\
\text { youth clubs/ } \\
\text { mahila mandal }\end{array}$ \\
\hline District Level & $\begin{array}{c}\text { Exec./Asstt Engg. } \\
\text { (PHED/RDD) / Zila }\end{array}$ & DMO & DPO/ICDS & NGO Personnel \\
\hline State Level & $\begin{array}{c}\text { Chief Eng./Chief } \\
\text { chemist }\end{array}$ & CMO & Director ICDS & NGO personnel \\
\hline
\end{tabular}

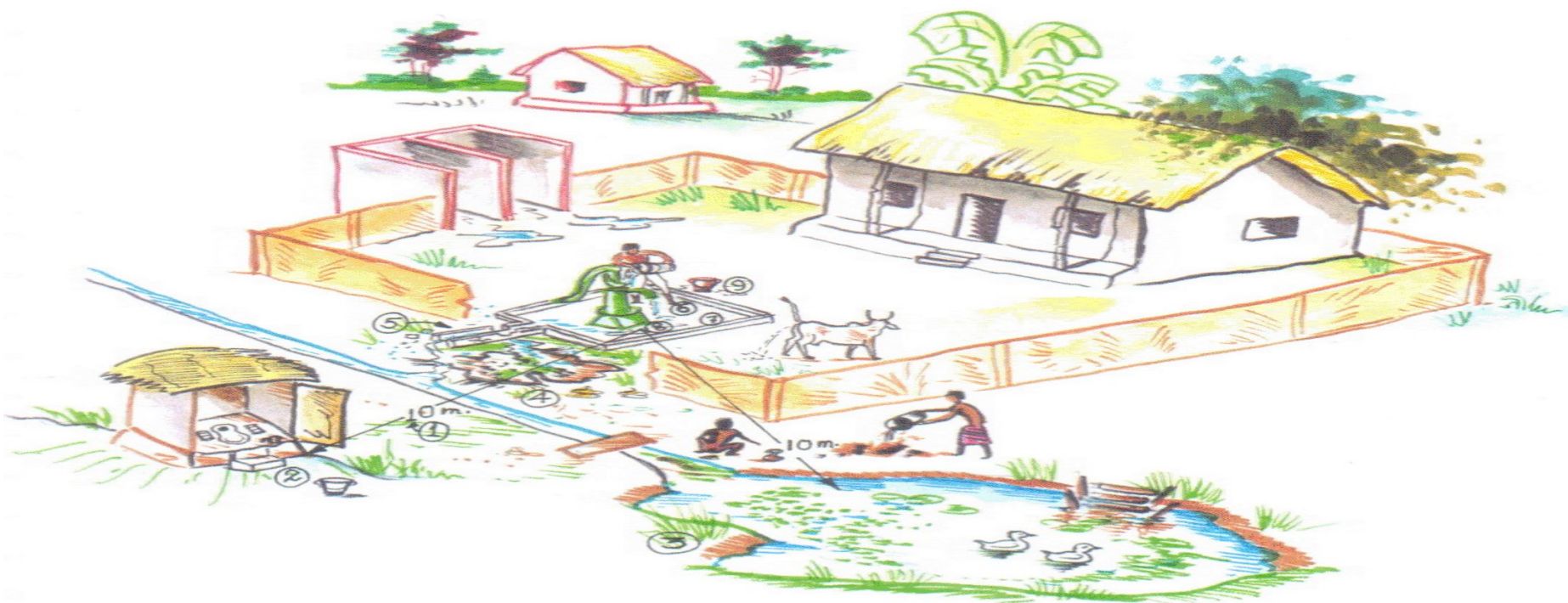




\section{CONCLUSIONS}

The results of household Fluorosis health survey conducted in 50 villages of 8 Tehsils of Nagaur District revealed the following facts:

$>$ Children to the tune of $39.2 \%(1,804$ nos. out of $4,603)$ are reported with Dental Fluorosis

$>$ Adult members of the households to the tune of $45.6 \%(6,242$ nos. out of 13,693$)$ are reported with Dental Fluorosis

$>$ Members of the households to the tune of $53.7 \%$ $(9,821$ nos. out of 18,296$)$ and $20 \%(3,659$ nos. out of 18,296) are reported with early warning signs and Skeletal Fluorosis respectively.

$>$ The population to the tune of nearly $69 \%(12,633$ out of 18,296 ) is consuming food items contaminated with fluoride unknowingly.

$>$ Nearly $44.2 \%$ (1,584 nos. out of 3582) families are aware about the Fluorosis disease.

$>$ The average awareness on Fluorosis among the surveyed population in the 8 Tehsils of Nagaur District is less than $50 \%$. However, in Nagaur and Jayal Tehsils it is comparatively very low i.e. 8.3 $\%$ and $20 \%$ respectively. In this regard, it is imperative to develop and disseminate appropriate communication materials depending on local conditions to increase the awareness level on Fluorosis. This would help in reducing the diseases burden due to Fluorosis.

$>$ Nearly $10.3 \%$ of households depend on private water tankers for their daily water needs. It would be appropriate to regulate and stipulate that water, which is a consumable entity like milk should be supplied in stainless steel tankers only. The water in stainless steel tankers can also be chlorinated in the tanker itself. Private contractors should not be allowed to provide water under unhygienic conditions and the quality of water need to be cross-checked.

$>$ As nearly $69 \%$ of surveyed respondents are consuming fluoride contaminated food items, Diet editing and Diet counselling need to be introduced with focus on elimination of excess fluoride ingestion through food, water and other sources.

$>$ As pregnant and lactating mothers are also living in all the endemic Tehsils of Nagaur district, it is also important to popularize the message that Fluoride is a poison and that it leads to anaemia in pregnancy, low birth weight babies and also leads to abortions/intrauterine deaths. Appropriate communication strategy need to be developed and popularized through all avenues, so that adolescent girls, pregnant and lactating mothers are adequately sensitized.

A high percentage of population i.e. $44.4 \%$ to $62.3 \%$ in all the 8 Tehsils suffer from early warning signs of Fluorosis, and as it is easily preventable, if all of them are aware about Do's and Don'ts on Fluoride and Fluorosis problems.

All the existing ground water sources need to be tested for fluoride and communities need to be sensitized on the harmful effects of consuming fluoride contaminated water, besides other food items. The survey data reveals that nearly

$35.6 \%$ of households depend on tube well water. Open well and hand pump water are the 2nd highest sources i.e. $14.8 \%$ and $13.9 \%$ respectively. Consumption of safe water from existing safe sources should be focused upon.

\section{Result}

A. Household of the villages adopted the techniques for the DFU water

B. Household have realized the importance of defluoride water

C. Local population now understood the real cause of spread of flour sis disease

D. Beneficiaries felt significant relief in several nonSkelton symptoms of flour sis i.e. recover of appetite, least backache, activity in daily routine life, decrease in gas formation, less thirsty, least joint pain, no stiffness in neck etc.

E. WATSAN committee, called pani samiti ( Village -Water and Sanitation Committee-VWSC) have been constituted in all the GPs to self sustain the ongoing programme

F. There is active participation of community elected representative, local schoolteachers, revenue officials, ASHA, ANM, AWW, Para medical staff

$\mathrm{G}$. Increased information education communication activities have awarded the people to use fluoride free water, uses of rain water and differential use of the water available.

H. Local persons trained

I. Close liaison between JICA, PHED, PRI, Health Department, and Education Department.

J. Proposed need base replication strategy stress for effective involvement of users and the government

K. Special schedules developed for house-to house survey, pre and post intervention medical examination of fluorosis patients and for fortnightly monitoring. 


\section{ACKNOWLEDGMENT}

I wish to express my sincere thanks and deep sense of gratitude to the Head of Department and my guide and Dr. Bharat Nagar, without whom, the work would have not been possible. The confidence with which Dr. Bharat Nagar guided the work requires no elaboration. His timely suggestions given and encouragement shown, made me more confident in successfully carrying out my project work.

\section{REFERENCES}

1. Mira Johri, Dinesh Chandra, S. V. Subramanium, Marie- Pierre Sylvestre, Smriti Pahwa. MDG 7c for Safe Drinking Water in India; an elusive achievement. The Lancent, Vol. 383 ISS 9926 pg 1379, 19 April 2014.

2. Gautam, R, Bhardwaj, N and Saini, Y. Study of fluoride content in ground water of Nawa Tehsil in Nagour, Rajasthan. Journal biology, (2011) 32(1) 85-89

3. Arif, M., Hussan, J, and kumar, S, Fluoride distribution in ground water and survey of Dental fluorosis in villages of Didwana Tehsil of Nagour district of central Rajasthan- Water, Energy and Food security. India water week (2012)

4. Burhan U. effect of fluoride on haemoglobin and hematocrit. Fluoride 1981; 14;38-41

5. Nanda R S. Flurodie content of North Indian food. Indian J Med Res 1972 60;1970-82

6. Susheela A. K., Mondal N K Anil Singh exposure to fluoride in smelter workers in a primary aluminium industry in India. Intl. J Occup Environ Med 2013 4;61-72

7. G S Toteja et al. prevalence of anaemia among pregnant women and adolescent girls in 16 districts of India. food and nutrition bulletin 2006;27(4)

8. A. K. Susheela treatise on flourosis $3^{\text {rd }}$ revised edition, 2007. Published by fluorosis foundation on India, new Delhi

9. A. K. Susheela fluorosis ; Guidelines for doctors for programme implementation 2014, published by fluorosis foundation of India

10. Public Health Engineering Department' bid document FMP. 